\title{
Physicochemical, sensory attributes and protein profile by SDS-PAGE of beef sausage substituted with texturized vegetable protein
}

\author{
Hidayat, B.T., Wea, A. and *Andriati, N \\ Department of Food Science and Agricultural Product Technology, Faculty of Agricultural Technology, \\ Gadjah Mada University, Jl. Flora, No.1 Bulaksumur Yogyakarta Indonesia 55281
}

\section{Article history:}

Received: 1 July 2017

Received in revised form: 31 July 2017

Accepted: 4 August 2017

Available Online: 6 August 2017

\section{Keywords:}

Beef sausage,

TVP,

Physicochemical properties,

Sensory properties,

Protein profile,

SDS-PAGE

\section{DOI:}

https://doi.org/10.26656/fr.2017.2(1).106

\begin{abstract}
The effect of texturized vegetable protein (TVP) on the quality of beef sausages was investigated in this research. Several formulations which replaced by beef meat with TVP ranging from $10-20 \% \mathrm{w} / \mathrm{w}$ were investigated for their physical, chemical, sensory properties and also protein profile by SDS-PAGE. The addition of TVP concentration significantly influences physicochemical characteristics e.g. water, fat content, the color parameter ( $\mathrm{L}$ and $\mathrm{b}$ value), WHC, Texture (Hardness) and cooking yield $(\mathrm{P}<0.05)$. The protein profile also influenced by the addition of TVP in beef sausage formula. Higher substitution of meat with TVP will increase the water and will decrease fat content significantly $(\mathrm{P}<0.05)$. The highest water content is $40 \%$ TVP $(64.02 \pm 1.15 \%)$ where the lowest water content is control $(61.29 \pm 1.88 \%)$. The highest fat content is control $(12.16$ $\pm 1.87 \%)$ where the highest fat content is $(8.53 \pm 2.09 \%)$. For the physicochemical properties, e.g. $\mathrm{L}^{*}$ and $\mathrm{b}^{*}$ value, WHC and Cooking yield will increase during the substitution of meat with TVP in sausage products $(\mathrm{P}<0.05)$. The hardness will decrease during the substitution of meat with TVP in sausage products $(\mathrm{P}<0.05)$. Sensory results indicated that sensory attributed of beef sausage showed good acceptance until $30 \%$ of TVP substitution.
\end{abstract}

\section{Introduction}

Protein is one of macronutrient in food. The food containing a high amount of protein is essential to contribute adequate nutrition. Several studies performed development of new sources of protein and the optimization of existing sources are issues of great interest and study (Asgar et al., 2010). The use of several ingredients beneficial to health such as has been equally identified as a steadily growing trend in the food industry. Nowadays, functional food refers to foods or food ingredients that can provide specific physiological beneficial effects and reduce the risk of several degenerative diseases (Ningrum, 2014; Rinaldoni et al., 2014; Shahidi and Ambigaipalan, 2015).

Sausage is a food that contains an amount of protein with a widespread consumption. Other than protein, it has a high content also with saturated and unsaturated fats that will contribute of calories and in general is an expensive product. Sausages as processed meat products are used in different and diverse cultures around the world. Sausage industries need to select a number of various ingredients in the appropriate amount to manufacture not just to obtain the desired quality and safe product, but also maintain cost effectiveness (Savadkoohi et al., 2014). So, it is a challenge for the food industry to formulate healthy sausage that can help to lower the health risk, as in the case of substituting animal fats by vegetable fats and oils, obtaining foodstuffs low in cholesterol and saturated fats (Rinaldoni et al., 2014; Savadkoohi et al., 2014). In this sense, the sausage is a good matrix to incorporate with vegetable proteins. Thus, sausage analogs, imitation sausage or non-meat sausage are gaining acceptance by the consumers because of many health benefits (Asuming-bediako et al., 2014; Savadkoohi et al., 2014; Riazi et al., 2016). Nowadays, the increasing consumer demands for meat and also non-meat or meat free (hybrid) sausages will encourage formulated several meat products to use novel processing technologies and new ingredient systems. In this recent years, there have been several noticeable increases in the application of substituted vegetable protein, fibers and also hydrocolloids (Weiss et al., 2010). The inclusion of these several functional ingredients in the formulation of meat product will also lead to desirable properties and also 
could improve the image of sausages for health benefits.

Between vegetable proteins, soybean highly contains well-balanced amino acids and also desirable fatty acids and it will play an important role as a protein source for people around the world (Rodri et et al., 2007; Zarkadas et al., 2007). Furthermore, it must be considered also that the cost of producing of sausage analogs can be less than that product obtained uniquely from animal proteins. There are various food formulations that incorporate soy proteins for various purposes.

Traditionally, soy flour and soy protein concentrates have been the principal source of raw material for the majority of commercially textured protein ingredients. However, products comprised of wheat gluten and other vegetable protein provide an endless array of TVP that can be utilized as meat extenders and meat analog products (Orcutt et al., 2006; Strahm, 2006).

In addition, products such as full-fat soy flour partially hydrolyzed soy proteins, and products based on traditional oriental food patterns are also available. The generic terms texturized vegetable protein, typically mean defatted soy flour or concentrates, mechanically processed by extruders to obtain meat-like chewy textures when rehydrated and cooked. Defatted soy particles (flakes and grits) and shaped soy protein isolates (sometimes called structuring proteins to differentiate them from extruded products) also are innovatively used to add texture and appeal to food products. Additional benefits of extrusion cooking are denaturing of the proteins, inactivation of trypsin inhibitors, control of bitter flavors, and the homogenous bonding of ingredients that may include several parameters e.g. colors, chemicals, and other additives, which all can have an influence on appearance or textural quality (Bjorck, 1983; Hayakawa et al., 1988). The objectives of this study were to develop a beef sausage substituted with different level of texturized vegetable protein (TVP) and to determine the effect of the incorporation of TVP in the matrix of beef sausage with the respect to the physicochemical and sensory properties.

Analysis of protein profiles of several sausages was analyzed using SDS-PAGE. This method uses the principle of separation of proteins based on molecular weight differences. Protein is passed in the inert gel (in this case polyacrylamide gel) using an electric charge. The protein has been denatured and would negatively charge through pore gel, so the migration rate will vary based on the weight of protein molecules. Higher molecular weight protein will lag behind because it will be more difficult to pass through the pores of the gel, and vice versa. Protein bands were separated then be identified by comparing the molecular weight markers used were based on the value of $\mathrm{Rf}$ (retention factor).
SDS-PAGE patterns have been extensively used for the development of methods aimed at the detection and authentication of the species present in food products. Although nowadays there is a general tendency within the proteomics community to move to gel-free workflows, the fact remains that electrophoresis e.g. SDS -PAGE has been extensively used and continues to be used in food authentication studies (Ortea et al., 2012).

\section{Materials and methods}

\subsection{Materials}

Materials needed are Ground beef, Texturized Vegetable Protein (TVP), ISP flour, tapioca flour, salt, sugar, ice water, garlic powder, white pepper powder, vegetable oil, STPP (Sodium Tri Polyphosphate) were purchased from local market SUPERINDO, Jalan Kaliurang, Yogyakarta, Indonesia. The local market is located between $7^{\circ} 47^{\prime}$ latitude and $110^{\circ} 22^{\prime}$ longitude.

\subsection{Sausages formulation}

Preparation of beef sausages substituted with TVP formulations was done (Table 1). The ground beef mixed with several ingredients in a food processor (KENWOOD Major). The batter was then prepared and then stuffed in casings (cellulose casing) by using a hand operated stuffer. Afterward, the sausages were boiled at $85^{\circ} \mathrm{C}$ for 10 minutes, and the products were cooled down in ambient temperature. Each formula can produce 10 sausages with diameter $1.6 \mathrm{~cm}$ and length $10 \mathrm{~cm}$ in each replication. The sausage then was analyzed for physicochemical properties. In TVP added formulation processing, the TVP was replaced for beef meat at the level of $10 \%, 20 \%, 30 \%$, and $40 \%$. The TVP was hydrated with distilled water at $50^{\circ} \mathrm{C}$ for 15 minutes prior to use.

\subsection{Chemical composition (protein content, fat content, and water content)}

Protein, fat, ash water content was determined in triplicate according to the method described by AOAC (AOAC, 2000). All measurements were performed in triplicate.

\subsection{Color measurements}

Color measurements were performed with Chroma Meter (Minolta CR 400, Japan). The instrument was calibrated with white calibration plate before the measurement. We used The Chroma Meter has aperture $0.8 \mathrm{~cm}$ and the white calibration plate/standard observer was used for a calibration prior to sample analysis $(\mathrm{Y}=$ $86.51 \mathrm{x}=0.3168$ and $\mathrm{y}=0.3245)$. The sausage was sliced approximately $15 \mathrm{~mm}$ thick piece and then the internal color (International Commission on Illumination $\mathrm{L}^{*}, \mathrm{a}^{*}$, $b^{*}$ ) of precooked sausage samples were measured (Jung 
Table 1. Beef sausages formulation

\begin{tabular}{lccccc}
\hline \multirow{2}{*}{ Material } & \multicolumn{5}{c}{ Weight (gram) } \\
\cline { 2 - 6 } & Control & $10 \%$ & $20 \%$ & $30 \%$ & $40 \%$ \\
& TVP & TVP & TVP & TVP \\
\hline ISP & 20 & 20 & 20 & 20 & 20 \\
Tapioca starch & 10 & 10 & 10 & 10 & 10 \\
Ground beef & 100 & 90 & 80 & 70 & 60 \\
meat & 0 & 10 & 20 & 30 & 40 \\
TVP & 10 & 10 & 10 & 10 & 10 \\
Palm oil & 3 & 3 & 3 & 3 & 3 \\
Salt & 1 & 1 & 1 & 1 & 1 \\
Sugar & 0.3 & 0.3 & 0.3 & 0.3 & 0.3 \\
Pepper & 25 & 25 & 25 & 25 & 25 \\
Ice & 50 & 50 & 50 & 50 & 50 \\
Water & 1 & 1 & 1 & 1 & 1 \\
Garlic powder & 0.5 & 0.5 & 0.5 & 0.5 & 0.5 \\
STPP & & & & & \\
\hline
\end{tabular}

et al., 2012). To determine differences in color values to visually perceived differences, the calculation of $\Delta \mathrm{E}$ was made with the following equation:

where $\Delta \mathrm{E}$ is the square root of the sum of squares of the differences between $\mathrm{L}^{*}, \mathrm{a}^{*}$, and $\mathrm{b}^{*}$ coordinates of samples and control formulation (without the addition of TVP).

Color parameters that are observed on sausage formula including Lightness $\left(\mathrm{L}^{*}\right)$, redness $\left(\mathrm{a}^{*}\right)$, and yellowness $\left(\mathrm{b}^{*}\right)$, and $\Delta \mathrm{E}$. Value $\mathrm{L}$ represents the brightness (lightness) of the sample. While the value of $+\mathrm{a}$ represents the red color of the sample. The higher the + a value, the redder the color of a sample, conversely the lower the value of -a sample of the color will be green. The value of $b$ is the yellow-blue color, the higher the

$$
\Delta \mathrm{E}=\sqrt{\left(\mathrm{L}_{2}^{\prime}-\mathrm{L}_{1}^{\prime}\right)^{2}+\left(\mathrm{a}_{2}^{\prime}-\mathrm{a}_{1}^{\prime}\right)^{2}+\left(\mathrm{b}_{2}^{\prime}-\mathrm{b}_{1}^{\prime}\right)^{2}}
$$

value of $+b$, the sample will be yellow, and lower of $-b$ value sample color will be blue. While the value of the color difference $(\Delta \mathrm{E})$ represents the target (sample) with the control. The larger the value, the greater AE color difference between the two samples, and vice versa.

\section{5. pH measurements}

The $\mathrm{pH}$ was measured in triplicate using a digital $\mathrm{pH}$ meter (MP230, Mettler Toledo, Switzerland). Approximately $1 \mathrm{~g}$ of the sample was grounded then and mixed with $9 \mathrm{~mL}$ of distilled water, and the $\mathrm{pH}$ was measured by using $\mathrm{pH}$ meter. All measurements were performed in triplicate. The $\mathrm{pH}$ meter was calibrated daily with standard buffers of $\mathrm{pH} 4.0$ and 7.0 at $25^{\circ} \mathrm{C}$ (Jung et al., 2012).

\subsection{Water holding capacity (WHC) measurements}

The WHC of different beef sausage samples were measured according to the previous method (Soeparno, 1992). All measurements were performed in triplicate

\subsection{Texture profile measurements}

The textural property (Hardness) was determined using Texture Analyzer (Universal Testing Machine). After peeling off the casing, texture profile was performed using the central cores from three slices of each cooked sausages (Jung et al., 2012). All measurements were performed in triplicate.

\subsection{Cooking yield measurements}

Cooking yield is performed to determine the effect of cooking to the weight of sausage (Jung et al., 2012). One $\mathrm{cm}$ of sausage was prepared then boiled in $100^{\circ} \mathrm{C}$ water for $2 \mathrm{~min}$. The weight before and after cooking was determined. The formula for cooking yield (CY) is

$\mathrm{CY}=$ weight after boiling (g) / weight before boiling ( $\mathrm{g}$ ) $\mathrm{x} 100 \%$

All measurements were performed in triplicate

\subsection{Sensory evaluation}

Sensory analysis was performed by undergraduate students in the Department of Food Science and Agricultural Product Technology, Faculty of Agricultural Technology, Gadjah Mada University, Yogyakarta Indonesia that is located between $7^{\circ} 46^{\prime}$ and $110^{\circ} 21^{\prime}-$ $110^{\circ} 22^{\prime}$ Longitude.

Panelists were seated in individual booths, in sensory analysis laboratory in Department of Food Science and Agricultural Product, UGM. Panels were convened for a total of three sessions for testing three replications of each treatment. Sensory evaluation was conducted by 30 panelists including several parameters e.g. texture, taste, flavor, color, and overall acceptability. Sausages were cut into $3 \mathrm{~cm}$ long slices. The slices were distributed in white plates and presented to the panelist in random order for evaluation. Mineral water was supplied to the panelist for rinsing between samples. The evaluation was also performed in a room specifically for sensory evaluation. The panelist was asked to score several sensory parameters of the product using 5-point hedonic scales. Panelists asked to indicate how much they like or dislike each product on a 5 -point hedonic scale $(5=$ like extremely, $4=$ like moderately, $3=$ neither like nor dislike, 2 = dislike moderately, 1 = dislike extremely) according to texture, taste, flavor, color and overall acceptability characteristic. The sensory evaluation was conducted in an appropriately designed and lighted room and a mean score was estimated for each product.

\subsection{Protein profile by SDS-PAGE}

SDS-PAGE was used as a separation technique to 
diversify and also disassociate proteins according to the protein size after extracting them (Aktas, 2005). It was carried out on gradient slab gel, employing the discontinuous buffer system (Baldermann et al., 2011). The protein band on SDS-PAGE gel then analyzed by using Image J software $1.51 \mathrm{j} 8$ version $(\mathrm{NIH}$, Bethesda, MD; http://imagej.nih.gov).

\subsection{Statistical analysis}

The experiments were designed as a complete randomized block with three separate replications. All statistical analysis was performed using SPSS 16 computer program from Windows. The significant differences between samples, between several substitutions beef meat with TVP were determined using analysis of variance test and performed with A Tukey test, with a significance level $\mathrm{P}<0.05$.

\section{Results and discussion}

\subsection{Chemical composition (water, fat, protein)}

Textured vegetable protein is physically removed skin and taken oil with a solvent and then processed through one or two extruder that has a texture like meat (Das et al., 2008). From this process, Texturized Vegetable Protein (TVP) has a lower fat content than beef and will influence the chemical composition of the sausage. Differences in chemical composition can impact on differences in physical properties of the sausage can also change consumer acceptance of sausages. The results of a chemical composition including water fat and protein contents in sausages could be the basis of differences in physical properties that might occur due to the replacement of beef with TVP. Mean percentages of water content, protein, and fat of sausages in a different level of TVP submission are shown in Table 2.

From the Table 2, the water content tends to increase with the substitution of TVP in sausage formula. During the sausage preparation, TVP was soaked in water (rehydration) before use so that the water content in TVP will increase. Thus, the increase in substitution of beef with TVP caused an increase in water content of sausage. On the other hand, substitution or replacement of beef meat with TVP started with the concentration 20, 30, $40 \%$ will affect significantly the water content rather than control $(\mathrm{P}<0.05)$. The higher water content also found in the other meat product substituted with soy protein since previously (Akesowan, 2008; Das et al., 2008).

The protein content in several formula was not affected significantly by increased substitution of beef with TVP $(\mathrm{P}>0.05)$. The same result also obtained with the soy protein substituted in pork meat sausage (Akesowan, 2008). On the other hand, the fat content decreased significantly with increasing percent substitution of TVP in sausage formula, because of the fat content of TVP much lower than the beef meat $(\mathrm{P}<0.05)$. TVP fat content ranged from 0.5-1.0, the numbers are very low because of the manufacturing process carried out the removal of fat with non-polar solvents such as hexane (Asgar et al., 2010). Studies of this substitution effect against fat sausages important because differences in fat content have the potential to affect some other test parameters in this study such as hardness. Of the three compositions that have been analyzed, the results are in line with research conducted by suggested substitution of goat meat with Texturized Vegetable Protein (TVP) to significantly raise the level of water and lower fat content of meat product (Akesowan, 2008; Das et al., 2008).

\subsection{Color}

The color is one of the important physical properties

Table 2. Means and standard errors for water content, protein content and fat content for all sausage formulation

\begin{tabular}{lccccc}
\hline & \multicolumn{5}{c}{ Formula (\% meat substituted with } \\
\cline { 2 - 6 } Parameter & 0 & 10 & 20 & 30 & 40 \\
& $\%$ & $\%$ & $\%$ & $\%$ & $\%$ \\
\hline \multirow{2}{*}{ Water } & 61.29 & 62.67 & 63.30 & 63.67 & 64.02 \\
Content & \pm & \pm & \pm & \pm & \pm \\
& $1.88^{\mathrm{a}}$ & $1.30^{\mathrm{ab}}$ & $1.19^{\mathrm{b}}$ & $1.67^{\mathrm{b}}$ & $1.15^{\mathrm{b}}$ \\
Protein & 14.02 & 16.05 & 15.66 & 15.22 & 14.1 \\
Content & \pm & \pm & \pm & \pm & $5 \pm$ \\
& $2.29^{\mathrm{a}}$ & $1.51^{\mathrm{a}}$ & $2.46^{\mathrm{a}}$ & $1.78^{\mathrm{a}}$ & $1.48^{\mathrm{a}}$ \\
Fat & 12.16 & 11.95 & 10.57 & 10.19 & 8.53 \\
Content & \pm & \pm & \pm & \pm & \pm \\
& $1.87^{\mathrm{a}}$ & $1.36^{\mathrm{a}}$ & $1.89^{\mathrm{ab}}$ & $1.19^{\mathrm{ab}}$ & $2.09^{\mathrm{b}}$ \\
\hline
\end{tabular}

${ }^{a-b}$ Means within the same row with different superscripts
differ significantly $(\mathrm{P}<0.05)$.

in determining consumer acceptance of the product. The effect of the substitution of beef meat with TVP on CIE color of sausages is presented in Table 3. From the results, it can be seen that the substitution of beef with TVP significantly $(\mathrm{P}<0.05)$ increased the value of $\mathrm{L}$ and b sausage but not significantly $(\mathrm{P}>0.05)$ influenced on the value of a. Thus, the addition of sausages TVP makes the colors become brighter and yellowish. The reason because of substitution of beef meat with TVP will cause the lower concentration of beef pigment e.g. myoglobin bright red (when in form deoxymyoglobin) that is replaced by TVP that have more bright yellowish color (Asgar et al., 2010).

During the process, the pigment of beef which is myoglobin can be changed to form derivatives. During the addition of TVP, the value of $\mathrm{L}^{*}$ and $\mathrm{b}^{*}$ tend to increase and significantly different $(\mathrm{P}<0.05)$. $\mathrm{L}^{*}$ value increases with an increased level of substitution of meat with TVP that will influence the concentration of natural pigment of meat pigments such as myoglobin, metmyoglobin, and other derivatives and oxidation of the 
Table 3. Means and standard errors for $\mathrm{L}^{*}, \mathrm{a}^{*}, \mathrm{~b}^{*}, \Delta \mathrm{E}, \mathrm{pH}$, hardness, WHC and cooking yield for all sausage formulation

\begin{tabular}{lccccc}
\hline \multirow{2}{*}{ Parameter } & \multicolumn{5}{c}{ Formula $(\%$ meat substituted with TVP) } \\
\cline { 2 - 6 } & 0 & 10 & 20 & 30 & 40 \\
\hline $\mathrm{L}^{*}$ & $47.98 \pm 1.50^{\mathrm{a}}$ & $47.43 \pm 1.74^{\mathrm{a}}$ & $48.01 \pm 0.85^{\mathrm{a}}$ & $50.21 \pm 1.21^{\mathrm{b}}$ & $51.95 \pm 1.50^{\mathrm{b}}$ \\
$\mathrm{a}^{*}$ & $5.66 \pm 0.70^{\mathrm{a}}$ & $5.62 \pm 0.97^{\mathrm{a}}$ & $5.83 \pm 0.93^{\mathrm{a}}$ & $5.77 \pm 0.35^{\mathrm{a}}$ & $5.43 \pm 0.25^{\mathrm{a}}$ \\
$\mathrm{b}^{*}$ & $7.87 \pm 0.44^{\mathrm{a}}$ & $7.86 \pm 0.75^{\mathrm{a}}$ & $7.94 \pm 0.54^{\mathrm{a}}$ & $8.49 \pm 0.36^{\mathrm{ab}}$ & $9.03 \pm 0.38^{\mathrm{b}}$ \\
$\Delta \mathrm{E}$ & - & 0,5515 & 0.1863 & 2.3172 & 4.1424 \\
$\mathrm{pH}$ & $6.45 \pm 0.11^{\mathrm{a}}$ & $6.50 \pm 0.04^{\mathrm{a}}$ & $6.525 \pm 0.05^{\mathrm{a}}$ & $6.51 \pm 0.05^{\mathrm{a}}$ & $6.49 \pm 0.08^{\mathrm{a}}$ \\
Hardness (N) & $1.0042 \pm 0.25^{\mathrm{b}}$ & $0.8053 \pm 0.05^{\mathrm{a}}$ & $0.6962 \pm 0.11^{\mathrm{a}}$ & $0.6981 \pm 0.15^{\mathrm{a}}$ & $0.6757 \pm 0.07^{\mathrm{a}}$ \\
WHC (\%) & $86.58 \pm 1.33^{\mathrm{a}}$ & $86.67 \pm 1.50^{\mathrm{a}}$ & $87.53 \pm 0.97^{\mathrm{ab}}$ & $89.02 \pm 0.96^{\mathrm{b}}$ & $89.14 \pm 1.75^{\mathrm{b}}$ \\
Cooking Yield & $100.39 \pm 0.92^{\mathrm{ab}}$ & $99.78 \pm 0.86^{\mathrm{a}}$ & $100.57 \pm 1 ., 20^{\mathrm{ab}}$ & $101.02 \pm 1.04^{\mathrm{ab}}$ & $101.58 \pm 1.13^{\mathrm{ab}}$ \\
$(\%)$ & & & &
\end{tabular}

${ }^{\mathrm{a}-\mathrm{b}}$ Means within the same row with different superscripts differ significantly $(\mathrm{P}<0.05)$.

fat that will give lighter color (Clair et al., 2016). Several lipid oxidation products, e.g. malonaldehyde will enhance meat discoloration that will cause increase of lightness $\left(\mathrm{L}^{*}\right)$ and decrease of yellowness value $\left(\mathrm{b}^{*}\right)$

In this study, yellowness value $\left(b^{*}\right)$ of sausage substituted with TVP was found to increase along with rising levels of substitution due to rising concentrations of TVP. It means that the substitution of TVP gave sausages to more yellowish. Substitution sausage with several fibers like tomato and other gave influence also to the increase of yellow color (Savadkoohi et al., 2014).

The redness $\left(\mathrm{a}^{*}\right)$ of meat products results from the presence of several heme proteins, hemoglobin and myoglobin in meat (Zhang et al., 2013). In this research, the value of redness of sausages substituted with TVP was not significantly different than the control $(\mathrm{P}>0.05)$.

On the other hand, the value of $\Delta \mathrm{E}$ tends to increase with rising levels of substitution. The difference between substitution treatment with significant control started at the level of substitution $40 \%$ (4.1424) or enter the range of change is. Level substitution with TVP in sausage under $40 \%$ only gives little color change and very little to control. The same result also obtained from the previous investigation, where the addition of pomace in sausage which contains higher fiber will also influence the increase of $\Delta \mathrm{E}$ value (Savadkoohi et al., 2014).Substitution of beef meat with grape pomace also influence the $\Delta \mathrm{E}$ value significantly $(\mathrm{P}<0.05)$ (Riazi et al., 2016). The $\Delta \mathrm{E}$ value significantly values of samples tend to increase the degree of meat substitution with other substitution material e.g. pomace or soy protein due to liable causes such as lipid oxidation, nonenzymatic browning reactions, myoglobin oxidation and others (Savadkoohi et al., 2014; Riazi et al., 2016).

\section{$3.3 \mathrm{pH}$}

From previous research of beef sausage, beef has a $\mathrm{pH}$ that is slightly acidic, ranging from 4-6 (Serdarog, 2008). Based on Table 3, from the research, the substitution of beef with TVP does not change significantly $\mathrm{pH}$ value of the sausage $(\mathrm{P}>0.05)$. The same result also obtained with the substitution of different level of soy protein concentration in goat meat nugget. Where the $\mathrm{pH}$ of the product didn't significantly influence by the addition of soy protein in the product formula ( $\mathrm{P}>0.05)$ (Das et al., 2008). The addition of other protein like gelatin in low-fat sausages also will not affect the $\mathrm{pH}$ value of the low-fat sausages (Lee and Chin, 2016). Substitution of cod meat with pea protein and carrageenan also had no effect on $\mathrm{pH}$ values in previous research (Cardoso et al., 2017). Different degree substitution of beef meat with camel meat also will not affect the $\mathrm{pH}$ values of sausages (Soltanizadeh $e t$ al., 2017).

In this research $\mathrm{pH}$ average of control and samples is approximately 6 . The various study has shown that $\mathrm{pH}$ is one of the fundamental factors that will also influence the texture of sausage. A pH increase of the meat batter to approximately 6 or higher has been advised in order to overcome product softness that will influence consumer acceptance (Cardoso et al., 2017).

\subsection{Water holding capacity (WHC)}

Water holding capacity or WHC is an indicator for measuring the ability of the sample (sausage) binds water or water is added during no influence from outside forces. In this study, WHC value is defined as the percentage of water that is bound in the sample after the sample is loaded with a certain specific time. Table 3 shows the value of WHC sausages with and without the addition of TVP.

From this research, the addition of TVP significantly increased the value of WHC sausage $(\mathrm{P}<0.05)$. WHC of samples varied from $86 \%$ to $89 \%$ and will increase along with substitution of beef with TVP $(0-40 \%)$. From these results, it can be concluded that the substitution of beef with TVP can improve WHC sausage. The increase of WHC in samples can be caused by several reasons. TVP has a protein content of more water soluble than beef so 
that it can bind to water better. In addition, TVP has a lower fat content than beef, where the absence of these fats makes the protein more freely bind water so the water holding capacity increases sausage. WHC is a crucial factor in determining the juiciness of meat products, in conjunction with flavor, texture, and also the color of meat products in the process of physical and chemical treatments (Feng et al., 2013). The control revealed the lowest WHC than the sausage samples added with TVP. Previous research showed that the addition of soy protein concentration proved to increase the water holding capacity in meat product (Das et al., 2008).

WHC was almost reaching the lowest point at IP (Isoelectric Point) of meat protein (approximately 5.2). With the increase of $\mathrm{pH}$, the total negative charge of myofibrillar proteins increases resulting in the enhancement of WHC in sausage substituted with gum or rice starch (Feng et al., 2013). The obtained results in this research are in line also with several types of research where the addition of protein like gelatin also will increase WHC in sausages (Lee and Chin, 2016; Souissi et al., 2016). The addition of other substitution material rich in protein and fiber e.g. collagen, fibers, rice bran and oatmeal will increase the WHC value of meat products, resulting in better texture and quality (Savadkoohi et al., 2014; Cardoso et al., 2017; Soltanizadeh et al., 2017).

TVP is a good source of insoluble dietary fiber which is polysaccharides type (Asgar et al., 2010). Functional properties of polysaccharides like insoluble dietary fiber in a food system broadly depend on waterpolysaccharides interaction. WHC represent the ability of a moist material to retain water. The addition of insoluble dietary fiber in sausage tends to increase WHC of sausages. WHC depends on pore size, conformational structure and also capillarity of the molecules. The latter is strongly correlated with the extent of molecule hydration with polar compounds along the hydrophilic interaction through the hydrogen bonding (Ktari et al., 2014). So, the addition of TVP in beef sausage formula is associated with the enhancement of the hydrophilic character.

\subsection{Texture}

The texture of the sausage is a very important parameter for the development of sausage products because of the texture influence consumer preferences towards the product. One parameter is the texture of hardness. Table 3 shows the hardness of several sausage formula (with and without the addition of TVP).

Based on Table 3, the addition of TVP significantly decreased the hardness of sausage $(\mathrm{P}<0.05)$. The substitution of meat with TVP will decrease the fat content and will influence the texture of sausage. Fatty acids without a double bond, or a saturated fatty acid (SFA), mostly have texture quite harder at room temperature and has a temperature higher melting point than unsaturated fatty acid (UFA). Substitution of beef with TVP can reduce fat content in sausage. Other reason can be influenced by the increase of water content in sausage substituted with TVP. The soft texture of rehydrated TVP and higher moisture content might be one of contributing factor the lower hardness in TVP extended sausage. The influence of beef meat substitution with other material like konjac jelly and pineapple fiber also decreased the hardness can be attributed to the addition of water (Akesowan, 2008; Ktari et al., 2014). Fat replacement with different fibers has been shown to improve textural properties by several researchers (Ktari et al., 2014; Clair et al., 2016).

The highest value of hardness at each sampling was observed for the control sausages (without the addition of TVP). The similar result also obtained with sausage substituted with plant rich of antioxidant activities, e.g. sage extract (Zhang et al., 2013). The hardness of sample can increase thought to results from emulsion destabilization caused by water and fat separation from the protein matrix. The reaction of protein oxidation may also lead to an increase of hardness through the formation of carbonyl the loss of protein functionality and also the formation protein cross-linking via disulfide bonding (Zhang et al., 2013). For these reasons, natural antioxidant like in TVP may reduce the hardness of the meat products by increasing emulsion stability and reducing the cross-linking through their protective role on proteins against oxidation (Asgar et al., 2010; Zhang et al., 2013; Aparecida et al., 2016). In combination with the previous research on the inhibitory effect of several plants contain antioxidant activities, it is plausible that antioxidant in TVP reduced the hardness increase in sausages through protein oxidation. The addition of other substitution like konjac gel in sausage will also decrease the hardness of sausages rather than control (Akesowan, 2008). The soluble dietary fiber in konjac gel and also in TVP acting as fat replacers provided mouth feel, texture and increased water holding capacity, which might cause the meat to be softer (Akesowan, 2008; Afoakwah et al., 2015).

\subsection{Cooking Yield}

Cooking yield is one important parameter in the manufacture of products. Because of differences in yield were small cooking alone is changing a lot of weight when sausages were produced on an industrial scale. Cooking yield in this study is defined as a percentage of the final weight compared to the initial weight after cooking by boiling. Mostly the cooking yield and moisture will affect the cost of manufactured processed meat products. Modification of these parameters can 
cause compositional changes in the finished product, which may modify palatability and textural characteristics (Pérez-chabela et al., 2013).

Cooking yield will increase significantly with the addition of TVP. Differences occurring protein makes the water binding in the sausage will potentially change. The results of cooking this yield can be correlated with the results of the WHC. Cooking yield also an indicator of water binding capacity of meat mostly affected by moisture, protein and fat content during meat processing (Afoakwah et al., 2015). Several types of research showed that Table 3 shows the yield sausage cooking with and without the addition of TVP. From the research, it showed that substitution of beef with TVP will significantly affect cooking yield $(\mathrm{P}<0.05)$. A similar result was observed by other researchers who showed that the addition of dietary fiber will enhance cooking yield due to a change of water and fat holding abilities ( Ktari et al., 2014; Afoakwah et al., 2015). The increase of cooking yield may be due to the high water holding capacity and the moisture absorption of the dietary fiber of TVP. The addition of TVP in other meat products e.g. nuggets will increase the cooking yield due to more water binging during cooking (Das et al., 2008).

\subsection{Sensory evaluation}

The level of consumer acceptance of sausage judged on four parameters e.g. appearance texture, flavor, and overall consumer preference towards sausages. Panelists asked to indicate how much they like or dislike each product on a 5 -point hedonic scale $(5=$ like extremely, 4 $=$ like moderately, $3=$ neither like nor dislike, $2=$ dislike moderately, $1=$ dislike extremely) according to texture, taste, flavor, color and overall acceptability characteristic. Table 4 shows the sensory evaluation results for beef sausage with and without the addition of TVP.

In the parameters, appearance and overall consumer acceptance significantly different with higher levels of substitution of beef meat with TVP $(\mathrm{P}<0.05)$. While the parameters of texture and flavor didn't significantly influence by the substitution of beef with TVP $(\mathrm{P}>0.05)$. In appearance parameters, the control value reached 5 score, which means panelists rather like extremely. On the other hand, the samples with TVP addition reached approximately scores 4 which like moderately the appearance of the sample.

In texture parameter, all treatments had a approximately mean score of 4 , means that the panelist like moderately the texture of sample or a preferred means of texture all samples. Consumer preferences texture of the sausage is influenced by various factors including those in this study examined, i.e. hardness, springiness, and juiciness. While on the flavor parameters as well as statistical test there was no significantly different between sample and control $(\mathrm{P}>0.05)$.

The last parameter is the overall consumer preferences towards samples. From the results of statistical analysis showed no significantly different between the control at the level of substitution of $10 \%$, $20 \%$, and $30 \%$, but began significantly different at the $40 \%$ level. These results indicate that the maximum substitution level can be done without significantly reducing consumer preferences towards beef sausage that is at the level of $30 \%$. This is reinforced by consumer preference value at $40 \%$ substitution level that touches the number 3, which means consumers are somewhat neither like or dislike of beef sausage.

\subsection{Protein profile of sausages by SDS-PAGE}

Adulteration of meat has become a serious problem recently. Interspecies differences in SDS-PAGE protein patterns between cattle, pig, chicken, turkey, duck, goose, etc., in both raw meat and processed products, have been investigated by several researchers (Montowska and Pospiech, 2013; Ortea et al., 2016). Some of the proteins were stable during meat aging and resistance to thermal processing, and some of them could even be identified in highly processed products such as fermented sausages and therefore proposed as suitable markers (Ahhmed et al., 2007). Proteins with species-

Table 4. Means and standard errors for sensory attributes by hedonic test

\begin{tabular}{lccccc}
\hline \multirow{2}{*}{ Parameter } & \multicolumn{5}{c}{ Formula (\% meat substituted with TVP) } \\
\cline { 2 - 6 } & 0 & 10 & 20 & 30 & 40 \\
\hline \multirow{2}{*}{ Appearance } & $5.04 \pm$ & $4.67 \pm$ & $4.50 \pm$ & $4.42 \pm$ & $4.17 \pm$ \\
& $1.16^{\mathrm{b}}$ & $1.13^{\mathrm{ab}}$ & $1.44^{\mathrm{ab}}$ & $1.06^{\mathrm{ab}}$ & $1.37^{\mathrm{a}}$ \\
\multirow{2}{*}{ Texture } & $4.50 \pm$ & $4.83 \pm$ & $4.29 \pm$ & $4.54 \pm$ & $4.00 \pm$ \\
& $1.25^{\mathrm{a}}$ & $1.43^{\mathrm{a}}$ & $1.52^{\mathrm{a}}$ & $1.35^{\mathrm{a}}$ & $1.35^{\mathrm{a}}$ \\
\multirow{2}{*}{ Flavor } & $4.58 \pm$ & $4.33 \pm$ & $4.33 \pm$ & $4.33 \pm$ & $3.79 \pm$ \\
& $1.14^{\mathrm{a}}$ & $1.40^{\mathrm{a}}$ & $1.34^{\mathrm{a}}$ & $1.34^{\mathrm{a}}$ & $1.22^{\mathrm{a}}$ \\
\multirow{2}{*}{ Overall } & $4.75 \pm$ & $4.54 \pm$ & $4.29 \pm$ & $4.46 \pm$ & $3.92 \pm$ \\
& $0.94^{\mathrm{b}}$ & $1.21^{\mathrm{ab}}$ & $1.40^{\mathrm{ab}}$ & $1.21^{\mathrm{ab}}$ & $1.02^{\mathrm{a}}$ \\
\hline
\end{tabular}

${ }^{a-b}$ Means within the same row with different superscripts differ significantly $(\mathrm{P}<0.05)$.

5 -point hedonic scale $(5=$ like extremely, $4=$ like moderately, 3 = neither like nor dislike, 2 = dislike moderately, $1=$ dislike extremely) according to texture, taste, flavor, color and overall acceptability characteristic).

specific expression and simultaneously not significantly degraded during processing could be used in authenticity tests of meat products made from the analyzed species. The methods like SDS-PAGE as one of proteomic approach may be applied not only to species identification but also to other authenticity issues (Montowska and Pospiech, 2013). 
The results of protein profile by SDS-PAGE on beef sausages with and without the addition of TVP can be seen in Figure 1. Lane 1 (far left lane) is a marker lane. Whereas lane 2, 3, 4, 5, and 6 showed protein profile of beef sausage without the addition of TVP, TVP beef sausage substitution with $10 \%, 20 \%, 30 \%$ and $40 \%$.

In lane 1 or marker, there are 6 bands with each band of known molecular weight. At $0.0922 \mathrm{Rf}$ are the largest molecular-weight proteins $(120 \mathrm{kDA})$ i.e. $\beta$ galactosidase. Then at $0.2937 \mathrm{Rf}$ is Bovine serum albumin protein band with a molecular weight of $90 \mathrm{kDa}$. The next four protein bands with Rf $0.4490 ; 0.7621$; 0.9247 ; and 0.9830 respectively was Ovalbumin $(50 \mathrm{kDa})$, Carbonic anhydrase $(34 \mathrm{kDa}), \beta$-lactoglobulin (26kDa) and Lysozyme (20kDa).

From the research results, obtained 15 protein bands in lane 2 or beef sausage without the addition of TVP. While 4 next lane (beef sausage with 10-40\% substitution TVP) relative has the same number of bands in lane 2 or control, but some of these bands have a tendency increasingly concentrated or fade due to rising levels of substitution of beef with TVP. Figure 1 shows the results of running the SDS-PAGE.

We determined protein band color intensity by ImageJ software. ImageJ will translate the intensity of color in the chart with a peak. The broad peak that determines how much the intensity of the color formed. The larger the area specific protein peak so the more of these proteins in the sample, and vice versa. Based on Table 5, showed the area specific protein peak with ImageJ.

From the analysis of the color intensity using ImageJ, it appears that the protein band with molecular weight of $80.82 \mathrm{kDa}, 76.87 \mathrm{kDa}$ and $45.70 \mathrm{kDa}$ decreased broad peak due to rising levels of substitution of beef meat with TVP, so that it can be assumed that the substitution of beef with TVP can reduce the concentration of these proteins in the sausage. Several tentative proteins tentatively identified as shown in Table 5. Myosin light chain and also actin are proteins that can be tentatively identified as a marker protein in sausage contain a low level of beef substitution with TVP. In the previous study, Myosin light chain isoforms retain their species-specific electrophoretic mobility after processing, including minced meat and also various meat products (Montowska and Pospiech, 2013). This myosin light chain is the group of regulatory proteins and metabolic enzymes in meat. Moreover, myosin is essential for texture properties of meat products (Ahhmed et al., 2007; Ali et al., 2015). It must, however, be recognized that other influential factors for textured properties of meat products are the cross-linking battlefield, such as actin (Ahhmed et al., 2007). The similar result on the texture results, where the hardness of sausage in a higher degree of substitution of beef meat

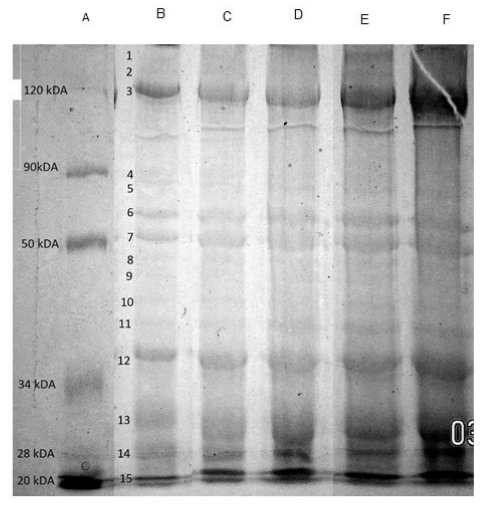

Figure 1. SDS-PAGE gel of several sausages with and without the addition of TVP and its marker.

Description: A $($ Lane 1) $=$ Marker, B $($ Lane 2$)=$ Control (substitution 0\%), C (Lane 3) = Substitution 10\%, D (Lane 4) $=$ Substitution $20 \%$, E (Lane 5) $=$ Substitution $30 \%$, and F (Lane 6) = Substitution $40 \%$

with TVP showed lower hardness level. Based on Table 5 , the peak area of actin and myosin in sausage with higher degree of substitution of beef meat with TVP are lower than the control (sausage without addition of TVP)

On the other hand, the protein band's peak with the molecular weight of $41.53 \mathrm{kDa}, 25.82 \mathrm{kDa}$, and $23.07 \mathrm{kDa}$ increased with increasing substitution of beef with TVP. This indicates that these proteins are likely to have a higher concentration on TVP than beef, so the increase in substitution of beef with TVP can increase the concentration of these proteins.

Several proteins in the globulin soybean are identified such as glycinin (11S globulin) and $\beta$ conglycinin (7S globulin) (Belitz et al., 2009). Conglycininin (11S globulin protein) is a hexamer and consists of five different subunits, each of which has a subunit A sour (acidic Pi) and subunit B (Pi bases). While glycinin (7S globulin) consisting of three subunits, $\alpha, \alpha$ ', and $\beta$ (Belitz et al., 2009). Based on Table 5, the peak area concentration of these proteins e.g. glycinin A and B in beef sausage partially substituted with TVP is a soy protein will increase with increasing levels of substitution of TVP.

\section{Conclusion}

Based on the research that has been done, it can be concluded that substitution of beef with TVP in beef sausage significantly increase the moisture content, lightness $\left(\mathrm{L}^{*}\right)$, yellowness $\left(\mathrm{b}^{*}\right)$, WHC, and cooking yield, and significantly decrease fat content and hardness. On the other hand, the substitution of beef with TVP did not significantly influence the redness $\left(a^{*}\right)$, protein content, and the $\mathrm{pH}$ value of beef sausage. Based on sensory evaluation results, the substitution of beef 
Table 5. Peak area of several protein bands beef sausage without and with the addition of TVP

\begin{tabular}{|c|c|c|c|c|c|c|}
\hline \multirow{2}{*}{$\begin{array}{l}\text { Molecular } \\
\text { Weight }\end{array}$} & \multicolumn{5}{|c|}{ Formula (\% meat substituted with TVP) } & \multirow{2}{*}{ Tentatively identified protein } \\
\hline & 0 & 10 & 20 & 30 & 40 & \\
\hline $80.82 \mathrm{kDa}$ & 1534.49 & 455.06 & - & - & - & $\begin{array}{l}\text { Myosin light chain } 1 \text { (Casserly et al., 2000; Claeys } \\
\text { et al., 2004; Ahhmed et al., 2007) }\end{array}$ \\
\hline $76.87 \mathrm{kDa}$ & 1091.91 & 678.56 & - & - & - & $\begin{array}{l}\text { Myosin light chain } 2 \text { (Casserly et al., 2000; Claeys } \\
\text { et al., 2004; Ahhmed et al., 2007) }\end{array}$ \\
\hline $45.70 \mathrm{kDa}$ & 1198.83 & 723.60 & - & - & - & $\begin{array}{l}\text { Actin (Casserly et al., 2000; Claeys et al., 2004; } \\
\text { Ahhmed et al., 2007) }\end{array}$ \\
\hline $41.53 \mathrm{kDa}$ & 1520.09 & 1944.92 & 1734.54 & 2734.29 & 2155.82 & $\begin{array}{l}\text { Glycinin A (Zarkadas et al., 2007; Chen et al., 2014; } \\
\text { Chen et al., 2016) }\end{array}$ \\
\hline $25.82 \mathrm{kDa}$ & 2811.07 & 2891.57 & 3658.43 & 4791.15 & 5791.15 & $\begin{array}{l}\text { Glycinin B3 (Zarkadas et al., 2007; Chen et al., } \\
\text { 2014; Chen et al., 2016) }\end{array}$ \\
\hline $23.07 \mathrm{kDa}$ & 2850.95 & 3703.99 & 3203.66 & 2150.88 & 3912.56 & $\begin{array}{l}\text { Glycinin B1 (Zarkadas et al., 2007; Chen et al., } \\
\text { 2014; Chen et al., 2016) }\end{array}$ \\
\hline
\end{tabular}

Description: - = peak area is very small

with TVP in sausage showed the optimal level of substitution at the level of $30 \%$, where at this level the overall consumer acceptance has not significantly different than the control. The protein profile of the sample by SDS-PAGE also influenced by the substitution of beef with TVP in beef sausage. Samples with a higher amount of beef meat contained more beef protein marker e.g. myosin light chain and actin protein. On the other hand, samples with a higher amount of TVP contained more soy protein marker e.g. glycinin (A and B). Future perspective of this study will lead to the importance of several characterizations of physicochemical, chemical, protein profile, sensory evaluation as tools for food authentication like in meat products. Nowadays, food adulteration has been found in many ways, so that it is important to authenticate the food based on their physicochemical, sensory or other characterizations.

\section{Conflict of Interest}

The authors declare no conflict of interest in the manuscript.

\section{Acknowledgment}

The authors wish to thank Faculty of Agricultural Technology, Universitas Gadjah Mada for RKAT Grant.

\section{References}

Afoakwah, N.A., Dong, Y., Zhao, Y., Xiong, Z., Owusu, J., Wang, Y. and Zhang, J. (2015). Characterization of Jerusalem artichoke (Helianthus tuberosus L.) powder and its application in emulsion-type sausage. LWT - Food Science and Technology, 64(1), 74-81. http://doi.org/10.1016/j.lwt.2015.05.030

Ahhmed, A.M., Kawahara, S., Ohta, K. and Nakade, K. (2007). Differentiation in improvements of gel strength in chicken and beef sausages induced by transglutaminase. Meat Science, 76, 455-462. http:// doi.org/10.1016/j.meatsci.2007.01.002

Akesowan, A. (2008). Effect of soy protein isolate on quality of light pork sausages containing konjac flour. African Journal of Biotechnology, 7(24), 4586 -4590 .

Aktas, N. (2005). Effect of microbial transglutaminase on thermal and electrophoretic properties of ground beef. LWT - Food Science and Technology, 38, 815819. http://doi.org/10.1016/j.lwt.2004.10.003

Ali, S., Zhang, W., Rajput, N., Khan, M.A., Li, C.B. and Zhou, G.H. (2015). Effect of multiple freeze-thaw cycles on the quality of chicken breast meat. Food Chemistry, 173, 808-814. http://doi.org/10.1016/ j.foodchem.2014.09.095

AOAC. (2000). Official Methods of Analysis. Washington DC: Association of Official Analytical Chemists Inc.

Aparecida, L., Alves, S., Manuel, J., Antonio, C., Gonçalves, A., José, A. and Campagnol, B. (2016). Production of healthier bologna type sausages using pork skin and green banana flour as a fat replacers. Meat Science, 121, 73-78. http://doi.org/10.1016/ j.meatsci.2016.06.001

Asgar, M.A., Fazilah, A., Huda, N., Bhat, R. and Karim, A.A. (2010). Nonmeat Protein Alternatives as Meat Extenders and Meat Analogs. Comprehensive Reviews in Food Science and Food Safety, 9, 513529. http://doi.org/10.1111/j.15414337.2010.00124.x

Asuming-bediako, N., Jaspal, M.H., Hallett, K., Bayntun, J., Baker, A. and Sheard, P.R. (2014). Effects of replacing pork backfat with emulsified vegetable oil on fatty acid composition and quality of UK-style sausages. Meat Science, 96(1), 187-194. http://doi.org/10.1016/j.meatsci.2013.06.031 
Baldermann, S., Mulyadi, A.N., Yang, Z., Murata, A., Fleischmann, P., Winterhalter, P. and Watanabe, N. (2011). Application of centrifugal precipitation chromatography and high-speed counter-current chromatography equipped with a spiral tubing support rotor for the isolation and partial characterization of carotenoid cleavage-like enzymes in Enteromorpha compressa. Journal of Separation Science, 34(19), 2759-2764. http://doi.org/10.1002/ jssc. 201100508

Belitz, H.D., Grosch, W. and Schieberle, P. (2009). Food Chemistry. Berlin, Heidelberg: Springer.

Bjorck, I.A.N. (1983). The effects of extrusion cooking on nutritional value - a literature review. Journal of Food Engineering, 2, 281-308.

Cardoso, C.M.L., Mendes, R., Nunes, M.L., Cardoso, C.M.L., Mendes, R., Instrumental, M.L.N. and Nunes, M.L. (2017). Instrumental Texture and Sensory Characteristics of Cod Frankfurter Sausages. International Journal of Food Properties, 12, 625-643. http:// doi.org/10.1080/10942910801992959

Casserly, Â., Mooney, M. and Troy, D. (2000). Standardisation and application of a semiquantitative SDS-PAGE method for measurement of myofibrillar protein fragments in bovine longissimus muscle. Food Chemistry, 69, 379-385.

Chen, J., Wang, J., Song, P. and Ma, X. (2014). Determination of glycinin in soybean and soybean products using a sandwich enzyme-linked immunosorbent assay. Food Chemistry, 162, 27-33. http://doi.org/10.1016/j.foodchem.2014.04.065

Chen, N., Zhao, M., Chassenieux, C. and Nicolai, T. (2016). Data in Brief Data on the characterization of native soy globulin by SDS-Page, light scattering and titration. Data in Brief, 9, 749-752. http:// doi.org/10.1016/j.dib.2016.10.016

Claeys, E., Smet, S. De, Balcaen, A., Raes, K. and Demeyer, D. (2004). Quantification of fresh meat peptides by SDS - PAGE in relation to aging time and taste intensity. Meat Science, 67, 281-288. http://doi.org/10.1016/j.meatsci.2003.11.001

Clair, S., Tshalibe, P. and Hoffman, L.C. (2016). Physico-chemical properties of reduced-fat beef species sausage with pork back fat replaced by pineapple dietary fibres and water. $L W T$ - Food Science and Technology, 74, 92-98. http:// doi.org/10.1016/j.lwt.2016.07.007

Das, A.K., Anjaneyulu, A.S.R., Gadekar, Y.P., Singh, R.P. and Pragati, H. (2008). Effect of full-fat soy paste and textured soy granules on quality and shelflife of goat meat nuggets in frozen storage. Meat Science, 80(3), 607-614. http://doi.org/10.1016/ j.meatsci.2008.02.011

Feng, T., Ye, R., Zhuang, H., Rong, Z., Fang, Z., Wang,
Y. and Jin, Z. (2013). Physicochemical properties and sensory evaluation of Mesona Blumes gum / rice starch mixed gels as fat-substitutes in Chinese Cantonese-style sausage. Journal of Food Resources, 50(1), 85-93. http://doi.org/10.1016/ j.foodres.2012.10.005

Hayakawa, I., Nayashi, N. and Urushima, T.F.F. (1988). Texturization of whole soybeans in a twin screw extruder. Faculty Agron Kyushu University, 33, 213 -220 .

Jung, E., Yun, I., Go, G., Kim, G., Seo, H., Joo, S. and Yang, H. (2012). Effects of radix puerariae extracts on physicochemical and sensory quality of precooked pork sausage during cold storage. LWT Food Science and Technology, 46(2), 556-562. http://doi.org/10.1016/j.lwt.2011.11.007

Ktari, N., Smaoui, S., Trabelsi, I., Nasri, M. and Ben, R. (2014). Chemical composition, techno-functional and sensory properties and effects of three dietary fibers on the quality characteristics of Tunisian beef sausage. Meat Science, 96(1), 521-525. http:// doi.org/10.1016/j.meatsci.2013.07.038

Lee, C.H. and Chin, K.B. (2016). Effects of pork gelatin levels on the physicochemical and textural properties of model sausages at different fat levels. LWT - Food Science and Technology, 74, 325-330. http:// doi.org/10.1016/j.lwt.2016.07.032

Montowska, M. and Pospiech, E. (2013). Speciesspecific expression of various proteins in meat tissue: Proteomic analysis of raw and cooked meat and meat products made from beef, pork and selected poultry species. Food Chemistry, 136(3-4), 1461-1469. http://doi.org/10.1016/ j.foodchem.2012.09.072

Ningrum, A. (2014). Pandan leaves: "Vanilla of the East" as potential natural food ingredient. Agro Food Industry Hi Tech, 25, 57-59.

Orcutt, M.W., McMindes, M.K., Chu, H. Mueller, I.N., Bater, B. and Orcutt, A.L. (2006). Textured soy protein utilization in meat and meat analog products. In Riaz, M.N. (Ed.) Soy Applications in Food. New York: CRC Press

Ortea, I., Connor, G.O. and Maquet, A. (2016). Review on proteomics for food authentication. Journal of Proteomics, 147, 212-225. http://doi.org/10.1016/ j.jprot.2016.06.033

Ortea, I., Pascoal, A., Cañas, B., Gallardo, J.M., BarrosVelázquez, J. and Carlo-Mata, P. (2012). Food authentication of commercially-relevant shrimp and prawn species: from classical methods to Foodomics. Electrophoresis, 33, 2201-2211.

Pérez-chabela, M.L., Díaz-vela, J., Reyes-menéndez, C.V, Díaz-vela, J., Reyes-menéndez, C.V, Pérezchabela, M.L. and Totosaus, A. (2013). Improvement of Moisture Stability and Textural 
Properties of Fat and Salt Reduced Cooked Sausages by Inoculation of Thermotolerant Lactic Acid Bacteria. International Journal of Food Properties, 16, 1789-1808. doi.org/10.1080/10942912.2011.608472

Riazi, F., Zeynali, F., Hoseini, E., Behmadi, H. and Savadkoohi, S. (2016). Oxidation phenomena and color properties of grape pomace on nitrite-reduced meat emulsion systems. Meat Science, 121, 350358. http://doi.org/10.1016/j.meatsci.2016.07.008

Rinaldoni, A.N., Palatnik, D.R., Zaritzky, N. and Campderrós, M.E. (2014). Soft cheese-like product development enriched with soy protein concentrates. LWT - Food Science and Technology, 55(1), 139147. http://doi.org/10.1016/j.lwt.2013.09.003

Rodri, R., Marina, M.L., Castro, F. and Garc1, M.C. (2007). Determination of soybean proteins in commercial heat-processed meat products prepared with chicken, beef or complex mixtures of meats from different species. Food Chemistry, 100, 468476. http://doi.org/10.1016/j.foodchem.2005.09.067

Savadkoohi, S., Hoogenkamp, H., Shamsi, K. and Farahnaky, A. (2014). Color, sensory and textural attributes of beef frankfurter, beef ham and meatfree sausage containing tomato pomace. Meat Science, 97(4), 410-418. http://doi.org/10.1016/ j.meatsci.2014.03.017

Serdarog, M. (2008). Effect of replacing beef fat with hazelnut oil on quality characteristics of sucuk - A Turkish fermented sausage. Meat Science, 78, 447454. http://doi.org/10.1016/j.meatsci.2007.07.013

Shahidi, F. and Ambigaipalan, P. (2015). Phenolics and polyphenolics in foods, beverages and spices: Antioxidant activity and health effects. Journal of Functional Foods, 18, 820-897. http:// doi.org/10.1016/j.jff.2015.06.018

Soeparno. (1992). Meat Technology. Indonesia: UGM Press.

Soltanizadeh, N., Kadivar, M., Keramat, J. and Bahrami, H. (2017). Camel cocktail sausage and its physicochemical and sensory quality. International Journal of Food Sciences and Nutrition, 61(2), 226243. http://doi.org/10.3109/09637480903373328

Souissi, N., Jridi, M., Nasri, R., Ben, R. and Njeh, M. (2016). Effects of the edible cuttlefish gelatin on textural, sensorial and physicochemical quality of octopus sausage. LWT - Food Science and Technology, 65, 18-24. http://doi.org/10.1016/ j.lwt.2015.07.051

Strahm, B. (2006). Meat Alternatives. In Riaz, M. N. (Ed.) Soy Applications in Food. New York: CRC Press.

Weiss, J., Gibis, M., Schuh, V. and Salminen, H. (2010). Advances in ingredient and processing systems for meat and meat products. Meat Science, 86(1), 196-213. http://doi.org/10.1016/ j.meatsci.2010.05.008

Zarkadas, C.G., Gagnon, C., Poysa, V., Khanizadeh, S., Cober, E.R., Chang, V. and Gleddie, S. (2007). Protein quality and identification of the storage protein subunits of tofu and null soybean genotypes, using amino acid analysis, one- and two-dimensional gel electrophoresis, and tandem mass spectrometry. Food Research International, 40, 111-128. http:// doi.org/10.1016/j.foodres.2006.08.005

Zhang, L., Lin, Y.H., Leng, X.J., Huang, M. and Zhou, G.H. (2013). Effect of sage (Salvia officinalis) on the oxidative stability of Chinese-style sausage during refrigerated storage. Meat Science, 95(2), 145 -150. http://doi.org/10.1016/j.meatsci.2013.05.005 
